\title{
APPLICATION OF INTERNET OF THINGS (IOT) TECHNOLOGY TO TRADITIONAL SHRIMP PONDS IN SRIMINOSARI VILLAGE, EAST LAMPUNG
}

\author{
Andi SETIAWAN1', Ni Luh Gede Ratna JULIASIH², Wawan Abdulah SETIAWAN³ \\ Jurusan Kimia FMIPA Universitas Lampung \\ Jl. Prof. Sumantri Brojonegoro No.1 Bandar Lampung 35145 \\ andi.setiawan@fmipa.unila.ac.id
}

\begin{abstract}
Traditional shrimp farmers at Sriminosari village still have problem to improve the productivity of their shrimp pond. Based on observation in the field, the low productivity of shrimp pond mainly due to the quality of water pond. Technology of the internet of things (IOT) is an alternative way to monitor some parameter their quality of water such as $\mathrm{pH}$ and temperature. Implementation of loT will give a simple way to monitor the quality of water in a real time and continues. Technically, technology of loT is not so expensive and easy to used for collecting data of quality water. So it is acceptable to implanted at Sriminosari village and useful to improve productivity shrimp farmer at Sriminosari village. Furthermore, information from loT data will help farmer shrimp to reduce the risk in their business. Starting from a forum disscussion group (FGD), the technology loT was introduced to some shrimp farmer at Sriminosari village. In general, The farmer gets basic knowledge about the concept of loT including the implementation in the field. In this program, parameter $\mathrm{pH}$ and temperature was selected as model to monitor water quality of shrimp pond. The result of measurement data temperature on the field showed that an averaged value of temperature relatively stable in normal range 26 $33^{\circ} \mathrm{C}$, while the value of $\mathrm{pH}$ is various and tend to over the lower limit $(<6.0)$. Based on collecting data of temperature and $\mathrm{pH}$ on the field, it can be concluded that implementing loT is very useful to assess the quality of water in shrimp farm. Furthermore, the respondents of shrimp farms indicated that implementation loT in shrimp is acceptable and promising to improve their shrimp farm productivity.
\end{abstract}

Keywords - Internet of Things (IoT), Water quality, Shrimp pond, Sriminosari, Lampung Timur

\section{PENDAHULUAN}

Saat ini, udang merupakan komoditas eksport andalan Indonesia. Lampung Timur merupakan salah satu sentra produksi udang di Indonesia dengan kapasitas produksi ekspor \pm 49,059.08 ton /tahun [Hastuti, 2017]. Melihat kondisi di lapangan, produktivitas tambak udang di kawasan Lampung Timur masih dapat ditingkatkan. Desa Sriminosari merupakan salah satu contoh kawasan tambak udang jenis vanname di Lampung Timur yang memiliki potensi untuk dapat dikembangkan. Namun, para petambak udang tradisional di Desa Sriminosari merasakan masih memerlukan bimbingan teknis terkait peningkatan produktivitas tambak udang mereka. 
Hasil survey lapangan menunjukkan sebagian besar petambak mengeluhkan adanya gejala kecenderungan penurunan produktivitas tambak dan munculnya White Feces Diseases (WFD) sehingga sangat sulit mendapatkan ukuran udang yang sesuai standard kebutuhan pasar. Analisis lebih lanjut data di lapangan mengindikasikan bahwa permasalahan tersebut terkait dengan kualitas air tambaknya. Hasil kajian akhir akhir ini juga mengindikasikan adanya potensi WFD untuk kawasan Lampung Timur [Supono et al., 2019]. Mempertimbangkan kerugian para petambak akan resiko yang diakibatkan oleh WFD maka dirasakan perlunya peningkatan kemampuan para petambak untuk dapat menjaga kualitas air tambak mereka.

Berdasarkan uraian di atas maka, pada kegiatan pengabdian ini, telah dikembangkan purwarupa sebuah sistem monitoring kualitas air tambak udang berbasis IoT. Sistem IoT ini dapat digunakan para petambak udang untuk memonitor parameter kimia dan fisika air tambak [Encinas et al., 2017]. Mempertimbangkan kemampuan petambak udang dalam hal biaya dan pengetahuan tentang parameter air maka implementasi loT untuk tahap awal dilakukan di desa Sriminosari sebatas parameter pH dan suhu. Pemantauan tersebut dilakukan secara online sehingga informasi dari kondisi air tambak di beberapa tambak terukur secara real time. Purwarupa loT yang dikembangkan dalam kegiatan pengabdian ini terdiri dari mikrokontroler NodeMCU V3 Lolin sebagai unit pemroses dan router berbasis modem WiFi 4G Telkomsel Wingle Softwifi Hotspot. Data yang didapatkan nantinya tidak hanya akan ditampilkan secara real time pada Google Spreadsheet, tetapi juga akan disimpan pada basis data dalam sistem penyimpanan Google Drive, sehingga data hasil pemantauan dapat digunakan untuk keperluan lebih lanjut. Informasi data parameter air tambak berbasis IoT tidak saja memberikan kemudahan bagi para petambak untuk mengetahui kualitas air tambak tetapi juga akan mempermudah dalam manejemen pengelolaan air tambak. Hal ini tentunya akan berdampak pada peningkatan produktivitas tambak udang dan pencegahan resiko penyakit udang.

\section{METODA PELAKSANAAN}

Program kegiatan Pengabdian Kepada Masyarat (PKM) ini, merupakan program kedua sebagai tindak lanjut program kegiatan di tahun sebelumnya terkait dengan pendampingan bimbingan teknis bagi para petambak udang di desa Sriminosari, Labuan Maringgai, Lampung Timur. Berdasarkan hasil diskusi dengan kelompok petambak, permasalahan utama yang dihadapi oleh para petambak saat ini adalah kecenderungan penurunan produktivitas tambak udang. Mempertimbangkan masalah yang ada, Tim PKM Unila memberikan bimbingan penerapan teknologi Internet of Things (IoT) guna mengatasi permasalahan monitoring parameter air tambak udang.

\section{METODE PENDEKATAN}

Untuk mengubah pola fikir yang selama ini diyakini oleh kelompok mitra pada umumnya bahwa pengelolaan tambak akan menambah beban biaya produksi, maka mainset kelompok mitra harus diubah menjadi petambak yang memiliki jiwa wirausaha, kreatif dan inovatif. Oleh karena itu, diharapkan dengan mainset yang baru dapat memajukan usaha tambak yang efisien, efektif dan berkesinambangan. Metode pendekatan yang ditawarkan kepada kelompok mitra sebagai solusi untuk menyelesaikan permasalahan yang ada saat ini meliputi:
A. Menjalin kerjasama Kelompok Petambak Maju Prima di Desa Sriminosari untuk kemudahan proses di lapangan.
B. Bimbingan teknis monitoring kualitas tambak udang berbasis teknologi loT seperti terlihat pada Gambar 1.
C. Pendampingan kepada Kelompok Petambak Maju Prima terkait interpretasi data analisis parameter tambak berbasis loT. 
D. Memberikan motivasi kepada kader kelompok mitra untuk mengelola tambak yang ramah lingkungan dan berkelanjutan.

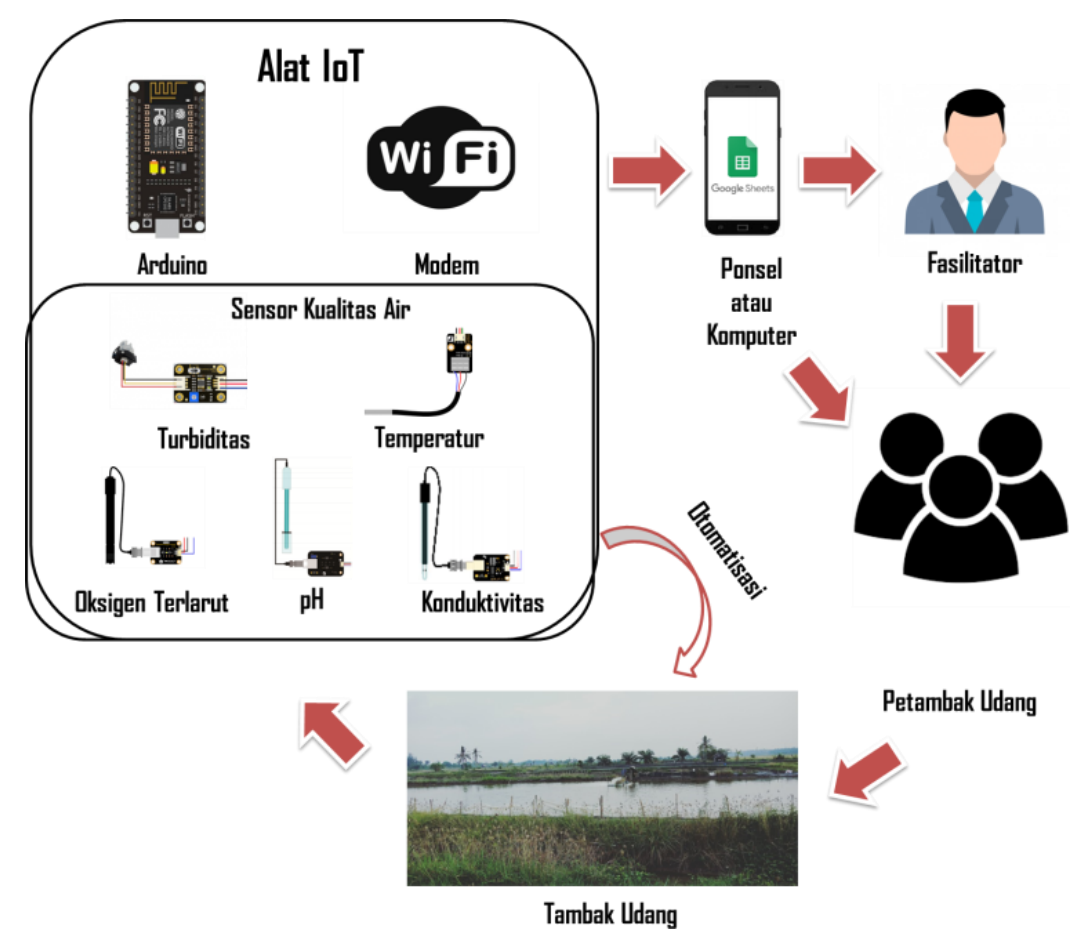

Gambar 1. Alur Proses Penerapan Teknologi loT untuk monitor kualitas air tambak secara real time dan berkelanjutan

Untuk menjamin keberhasilan kegiatan pengabdian ini, kelompok mitra, yakni Petambak Udang desa Sriminosari berperan sebagai subyek kegiatan sehingga nantinya diharapkan akan memiliki pengetahuan, keterampilan dan keahlian dalam mengaktifkan dan pengaplikasian loT pada kelompoknya masing-masing dalam upaya memonitor kualitas air tambak..

\section{Langkah-langkah Solusi}

Untuk menjamin terlaksananya kegiatan ini maka langkah-langkah solusi yang ditawarkan dan dilaksanakan dalam kegiatan ini meliputi tahapan:

A. Persiapan; Pembuatan 3 unit peralatan loT untuk memonitor parameter $\mathrm{pH}$ dan temperature

B. Tahap Pelaksanaan; kegiatan bimbingan teknis teori dan penerapan loTdi lapangan

C. Tahap Evaluasi; capaian Tujuan Instruksi Khusus

D. Tahap Pemantauan; kegiatan ini direncanakan dilakukan setelah 3 bulan kegiatan pengabdian untuk melihat keberlangsungan keberhasilan penerapan loT, maka indikator yang diamati adalah peningkatan produksi tambak udang. 


\section{HASIL DAN PEMBAHASAN}

Implementasi loT untuk memonitor kualitas air tambak secara real time dan terus menerus masih terbilang baru bagi kelompok petambak Mitra Maju di desa Sriminosari. Melalui Program Hibah Unggulan UNILA, Tim PKM berkejasama dengan pembina tambak di Desa Sriminosari telah memperkenalkan teknologi loT dan mengimplementasikannya pada tambak udang melalui beberapa tahapan kegiatan.

\section{Perakitan Peralatan loT}

Untuk tahap persiapan kegiatan pengabdian ini, Tim PKM Unila mengembangkan 3 unit purwarupa loT yang dilengkapi dengan 2 jenis sensor, pH dan temperatur, seperti terlihat pada Gambar 2.

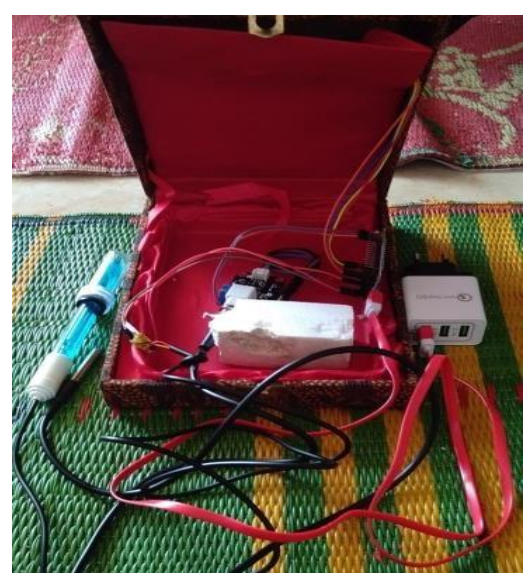

(a)

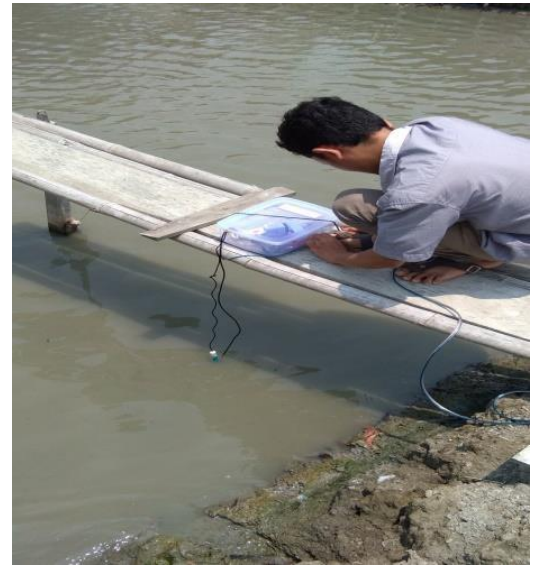

(b)

Gambar 2. Purwarupa loT yang dilengkapi dengan sensor $\mathrm{pH}$ dan temperatur.

(a) Purwarupa loT di Laboratorium Kelompok Petambak (b) Purwarupa loT di area Tambak Udang

Dalam kegiatan ini, ke 3 unit purwarupa loT digunakan untuk uji coba di lapangan (1 Unit), sebagai bagian laboratorium lapangan (1 Unit), dan peralatan standard pembanding pengujian (1Unit). Hasil uji coba di laboratorium selama 30 hari menunjukkan bahwa peralatan yang digunakan memberikan informasi data pengukuran $\mathrm{pH}$ dan temperatur yang cukup konsisten dan layak untuk digunakan di Tambak Udang.

\section{Bimbingan Teknis Penerapan loT pada Tambak Udang}

Tahap pelaksanaan kegiatan diawali dengan bimbingan teknis melalui forum diskusi kelompok (FGD). Kegiatan FGD diikuti oleh 20 peserta petambak udang. Para peserta mendapat pelatihan teori dasar berkenaan dengan cara kerja loT, interpretasi serta penggunaan data hasil pengukuran yang ditransmisikan melalui HP dan juga pemahaman lebih mendalam berkenaan parameter $\mathrm{pH}$ dan temperatur. 
Pemantauan parameter pH dan suhu dengan loT melalui uji coba pengukuran di lapangan, untuk waktu selama sembilan hari terlihat pada Gambar 3.

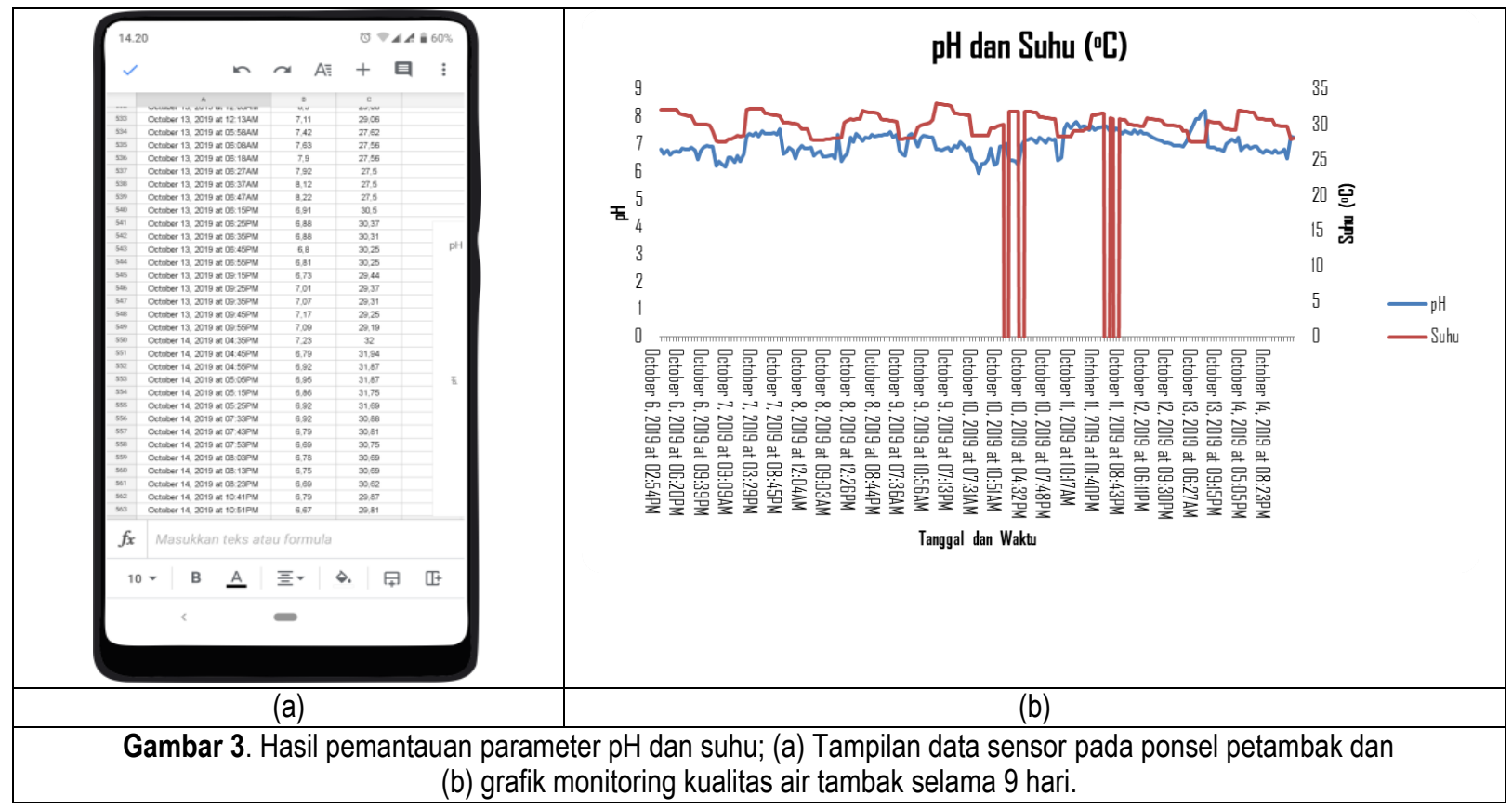

Pemilihan parameter $\mathrm{pH}$ dan temperature didasarkan akan pertimbangan bahwa para petambak telah terbiasa menggunakan kedua parameter tersebut dan data yang terukur memberikan informasi penting terkait kualitas air tambak. Temperature merupakan salah satu parameter fisik yang merupakan indikator penting berkenaan dengan peningkatan atau penurunan laju metabolik terkait proses pertumbuhan udang. Temperatur juga dapat mempengaruhi aktivitas metabolisme udang, karena itu penyebaran udang dibatasi oleh temperature perairan tersebut. Temperatur juga sangat berpengaruh terhadap pertumbuhan dan kehidupan biota air. Secara umum, laju pertumbuhan meningkat sejalan dengan kenaikan suhu, dapat menekan kehidupan hewan budidaya bahkan menyebabkan kematian bila peningkatan temperatur terjadi secara drastis [Wyban et al., 1995]. Lebih lanjut, Parameter pH berfungsi sebagai indikator untuk reaksi kimia dan biologi dalam metabolisme akuatik. Perairan asam akan kurang produktif, malah dapat membunuh hewan budidaya. Pada $\mathrm{pH}$ rendah (keasaman tinggi), kandungan oksigen terlarut akan berkurang, sebagai akibatnya konsumsi oksigen menurun, aktivitas naik dan selera makan akan berkurang. Hal ini sebaliknya terjadi pada suasana basa. Atas dasar ini, maka usaha budidaya perairan akan berhasil baik dalam air dengan pH 6,5 - 9,0 dan kisaran optimal adalah pH 7,5 - 8,7 [Furtado et al., 2015]. Hasil uji dilapangan menunjukan bahwa peralatan loT yang terpasang memberikan informasi data pengukuran yang tepat dan konsisten. Hasil evaluasi lebih lanjut terkait fluktuasi nilai pengukuran temperatur disebabkan oleh kesalahan teknis pengukuran dilapangan akibat posisi sensor yang tidak tepat. Hasil dari FGD juga memperlihatkan antusias para petambak yang berminat untuk memasang purwarupa loT di masing-masing tambak mereka dan mengusulkan adanya penambahan sensor pada unit loT, salah satunya parameter salinitas. 


\section{Capaian Tujuan Instruksional Khusus (TIK)}

Salah satu parameter keberhasilan kegiatan pengabdian kepada masyarakat tentang penerapan teknologi IOT pada tambak udang di Desa Sriminosari adalah adanya perubahan nilai capaian TIK yang diperoleh melalui evaluasi pre tes dan post tes. Kegiatan pre tes dilakukan untuk mengetahui pemahaman awal peserta terhadap hal berkaitan dengan loT. Setelah dilakukan sosialisasi dan pelatihan teknis, yang diikuti oleh 20 orang petambak udang maka di akhir kegiatan dilakukan post test untuk mengetahui perubahan kemampuan peserta terhadap materi pengabdian yang telah diberikan.

Hasil evaluasi menunjukkan adanya peningkatan pemahaman para petambak udang yang signifikan seperti terlihat pada Tabel 1 dan Gambar 4.

Tabel 1. Pengukuran capaian Tujuan Instruksional Khusus (TIK) terkait dengan pemahaman loT

\begin{tabular}{|c|c|c|c|c|}
\hline \multirow[t]{2}{*}{ No } & \multirow[t]{2}{*}{ Tujuan Instruksional Khusus (TIK) } & \multicolumn{3}{|c|}{ Pencapaian TIK (\%) } \\
\hline & & Pre test & Post test & Peningkatan \\
\hline 1 & Pengetahuan peserta tentang loT & 20 & 62 & 42 \\
\hline 2 & $\begin{array}{l}\text { Pengetahuan tentang beberapa parameter yang diterapkan } \\
\text { dalam loT }\end{array}$ & 15 & 47 & 32 \\
\hline 3 & $\begin{array}{l}\text { Pengetahuan peserta tentang peran parameter } \mathrm{pH} \text {, dan } \\
\text { temperatur }\end{array}$ & 17 & 48 & 31 \\
\hline 4 & $\begin{array}{l}\text { Pengetahuan peserta tentang faktor-faktor yang mempengaruhi } \\
\text { pertumbuhan udang }\end{array}$ & 18 & 64 & 46 \\
\hline 5 & $\begin{array}{l}\text { Pengetahuan peserta tentang mengatasi dan pencegahan } \\
\text { Penyakit udang }\end{array}$ & 28 & 78 & 50 \\
\hline & Rata-Rata & 19,6 & 59,8 & 40,2 \\
\hline
\end{tabular}

Rendahnya pengetahuan para petambak tentang kualitas air dan tata cara pengelolaan tambak dilatarbelakangi oleh rendahnya pendidikan rata-rata para petambak tersebut. Adanya sosialisasi dan pelatihan tentang pentingnya monitoring kualitas air tambak dengan teknologi loT ini telah berhasil meningatkan pengetahuan para petambak, yang tercermin dari peningkatan capaian TIK hingga 40,2\%. Peningkatan pengetahuan para petambak ini diharapkan akan memberikan peningkatan produktifitas tambak udang di Desa Sriminosari, sehingga nantinya akan dapat meningkatkan kesejahteraan para petambak.

\section{SIMPULAN}

Penerapan teknologi loT untuk memonitor kualitas air tambak memberikan dampak positip bagi kelompok petambak Maju Prima di Desa Sriminosari Kecamatan Labuan Maringgai, Lampung Timur. Secara teknis, para petambak juga telah memahami manfaat teknologi loT dan pentingnya memonitor parameter $\mathrm{pH}$ dan temperatur air tambak udang. Data pengukuran parameter tambak yang diperoleh secara real time dapat diterima oleh para petambak. Berdasarkan masukan dari mitra petambak Maju Prima, kegiatan di masa datang difokuskan pada pendampingan interpretasi data loT serta pengembangan penerapan loT. Terkait dengan penularan penyakit udang, para petambak juga berharap adanya bimbingan inovasi pengolahan limbah lumpur tambak udang yang selama ini dibuang ke kawasan mangrove di desa Sriminosari. 


\section{UCAPAN TERIMA KASIH}

Tim PKM mengucapkan terimakasih kepada LPPM Universitas Lampung untuk pendanaan PKM skema Unggulan Universitas Lampung Tahun Anggaran 2019 dengan kontrak No. 3575/UN26.21/PM/2019.

\section{REFERENSI}

Hastuti, M. S. (2017) Presentation 6: Country Presentation Indonesia. Retrieved from http://www.fao.org/fi/static-media/MeetingDocuments/WorkshopQingdao/6e.pdf

Supono, Wardiyanto, Harpeni, E., Khotimah, A. H., Ningtyas, A. (2019) Identification of Vibrio sp. as cause of white feces diseases in white shrimp Penaeus vannamei and handling with herbal ingredients in East Lampung Regency, Indonesia. AACL Bioflux, 12 (2), 417-425.

Encinas, C., Ruiz, E., Cortez, J., Espinoza, A. (2017) Design and implementation of a distributed loT system for the monitoring of water quality in aquaculture. 978-1-5090-3599-1/17IEEE.

Wyban, J., Walsh, W. A., Godin, D. M. (1995) Temperature effects on growth, feeding rate and feed conversion of the Pacific white shrimp (Penaeus vannamei). Aquaculture, 138, 267-279.

Furtado, P. S., Fugimura, M. M. S., Monserrat, J. M., Souza, D. M., Garcia, L. de O., Wasielesky, W. (2015) Acute effects of extreme $\mathrm{pH}$ and its influences on the survival and biochemical biomarkers of juvenile White Shrimp, Litopenaeus vannamei. Marine and Freshwater Behaviour and Physiology. DOI: 10.1080/10236244.2015.1086539. 